\title{
Antibacterial Non-Glycosidase Activity of Invertebrate Destabilase-Lysozyme and of Its Helical Amphipathic Peptides
}

\author{
L.L. Zavalova ${ }^{a}$ T.G. Yudina ${ }^{\text {b I.I. Artamonova }}{ }^{a}$ I.P. Baskova ${ }^{\text {b }}$ \\ ${ }^{a}$ Shemyakin-Ovchinnikov Institute of Bioorganic Chemistry, Russian Academy of Sciences, and \\ ${ }^{b}$ Biological Faculty, Lomonosov Moscow State University, Moscow, Russia
}

\section{Key Words}

Amphipathic peptides · Destabilase-lysozyme •

Invertebrate lysozymes · Non-enzymatic antimicrobial activity

\begin{abstract}
Background: Since bactericidal properties of some lysozymes are independent of their glycosidase activity, we have investigated this phenomenon for destabilase-lysozyme (DL) from medicinal leech (Hirudo medicinalis). Methods: Glycosidase activity was determined on Micrococcus luteus, non-enzymatic antibacterial activity of heat-treated DL and of synthetic peptides $\alpha 1, \alpha 2$ and $\alpha 3$ (fragments of its primary structure) on M. luteus, Escherichia coli, Bacillus brevis and Streptomyces chrysomallus. Results: Glycosidase activity disappeared after the heating of native $\mathrm{DL}$ at $100^{\circ} \mathrm{C}$ for $40 \mathrm{~min}$. Antibacterial activity of heat-treated DL for M. luteus MDMSU128 and MDMSU140 expressed as minimal inhibitory concentration was $9.8 \cdot 10^{-8}$ and $12 \cdot 10^{-8} M$, respectively, and to $E$. coli MDMSU52 $11 \cdot 10^{-8} \mathrm{M}$. Antibacterial activity of
\end{abstract}

Presented at the '1st World Conference on Magic Bullets - EHRLICH 2004', Nuremberg, Germany, September 9-11, 2004. synthetic peptide $\alpha 1$ for $M$. luteus MDMSU128 and for E. coli MDMSU52 was $8.3 \cdot 10^{-5}$ and $4.9 \cdot 10^{-5} \mathrm{M}$, respectively. Conclusion: DL is the first invertebrate lysozyme with combined enzymatic and non-enzymatic antibacterial action.

Copyright $(2006$ S. Karger AG, Basel

\section{Introduction}

Destabilase-lysozyme (DL) from medicinal leech $(\mathrm{Hi}$ rudo medicinalis) belongs to a new phylogenetic family of invertebrate lysozymes; native and recombinant enzymes destroy cell walls of Micrococcus luteus [1]. Over the last 10 years, some authors described bactericidal properties of lysozymes that were independent of their enzymatic activity. Non-enzymatic antibacterial function was found in chicken-, human- and T4-type lysozymes and in their helical fragments; denatured lysozymes lacking glycosidase activity are still able to inhibit bacterial growth [2]. Since information on non-enzymatic activity of invertebrate lysozymes is lacking, it was relevant to analyze its existence in DL, a representative of this type of lysozymes, and in some synthetic peptides, the fragments of DL helical amphipathic regions.

\section{KARGER \\ Fax +4161306 1234 E-Mail karger@karger.ch} www.karger.com
(C) 2006 S. Karger AG, Basel 0009-3157/06/0523-0158\$23.50/0

Accessible online at: www.karger.com/che
Dr. L.L. Zavalova

Shemyakin-Ovchinnikov Institute of Bioorganic Chemistry

Russian Academy of Sciences

Moscow 117997 (Russia)

Tel.+7 095330 7029, Fax +7 095330 6538, E-Mail saliva1@yandex.ru 
Fig. 1. Dependence of diameter $(\mathrm{mm})$ of inhibition zones of $M$. luteus (a) and $E$. coli (b) growth (Y-axis) on logarithm of denatured DL concentration $(\mu \mathrm{g} / \mathrm{ml})(\mathrm{X}$-axis), Chapek medium with $1.5 \%$ agar.
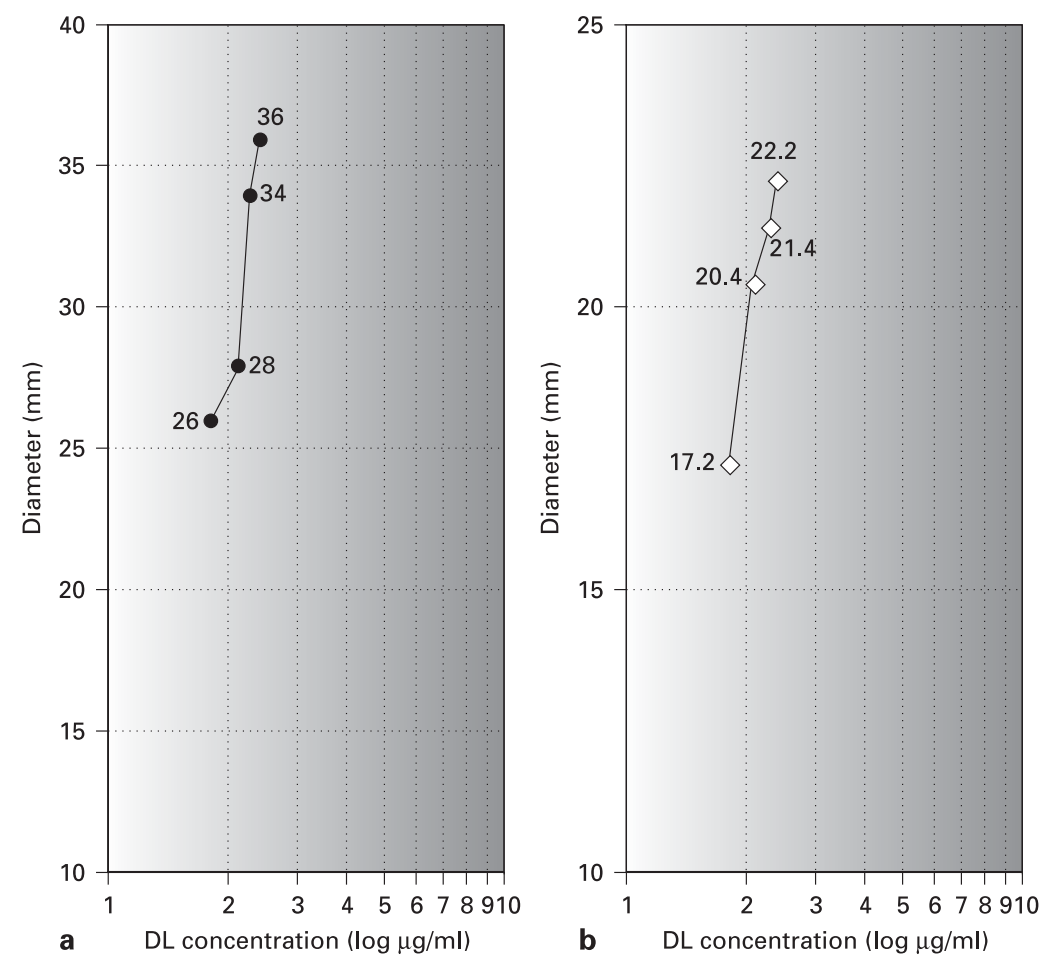

\section{Materials and Methods}

DL was prepared from the fine powder of dried medicinal leech (H. medicinalis) using a previously described method [3]. Enzymatic lysozyme activity was determined by lysis of $M$. luteus cell walls according to a previous study [1] and amounted to $18 \cdot 10^{4}$ units/mg. Non-enzymatic antibacterial activity of DL was determined using an agar diffusion method [4] with respect to $M$. luteus MDMSU128 and MDMSU140, and to Escherichia coli MDMSU52. Antibacterial activity of DL and synthetic peptides was determined in liquid medium [4] against the above-mentioned microorganisms and Bacillus brevis MDMSU3 and Streptomyces chrysomallus MDMSU257. Antibacterial activity was expressed as minimal inhibitory concentration (MIC). MIC is the minimal concentration suppressing the growth of tested microorganisms. All the microorganisms used were from the Museum of Microorganisms, Department of Microbiology, Moscow State University (MDMSU). Analysis of the primary DL structure [1] was performed on the basis of [5].

Previously established methods were used for the calculation of $\alpha$-helical structure hydrophobicity. On the basis of these data, three amphipathic peptides of $99 \%$ purity were synthesized in the Laboratory of Peptide Chemistry, Institute of Bioorganic Chemistry, Russian Academy of Sciences: $\alpha$ 1-HAYMDRYARRC (67-77 amino acid residues of DL), $\alpha 2-C Q D Y A K I H$ (85-92 amino acid residues of DL) and $\alpha 3$-YWDNVRRC (105-112 amino acid residues of DL). Chemicals of the highest available grade were purchased from Sigma (Sheboygan Falls, Wisc., USA), Fluka (Buchs, Switzerland), Calbiochem (Nottingham, UK) and Reakhim (Moscow, Russia).

\section{Results and Discussion}

\section{Antimicrobial Activity of Heat-Treated DL}

$\mathrm{DL}$ in $20 \mathrm{mM}$ Tris- $\mathrm{HCl}$ buffer, $\mathrm{pH} 7.2$ (protein concentration $0.08 \mathrm{mg} / \mathrm{ml}$ ), was incubated at $100^{\circ} \mathrm{C}$ for $5-$ $50 \mathrm{~min}$. Precipitated heat-denatured protein was removed by centrifugation at $16,000 \mathrm{~g}$ for $15 \mathrm{~min}$, and the residual glycosidase activity was determined. Heating for 5 min resulted in a $16 \%$ reduction in enzymatic activity, increasing to $22 \%$ for $20 \mathrm{~min}$. Total enzyme inactivation was achieved after heating for $40 \mathrm{~min}$ at $100^{\circ} \mathrm{C}$. Neither 10- nor 100-fold increases in the DL concentration nor doubling of the incubation time resulted in the appearance of residual enzymatic activity. Different amounts of DL heated for $40 \mathrm{~min}$ at $100^{\circ} \mathrm{C}$ were deprived of glycosidase activity, maintained homogeneity in PAGE and 
possessed antimicrobial (M. luteus and E. coli) activity (fig. 1). The logarithm of DL concentrations $(\mu \mathrm{g} / \mathrm{ml})$ is proportional to the diameter $(\mathrm{mm})$ of the zones of the growth inhibition of the microorganisms tested, being typical for different antibiotics [5]. MICs of heat-treated DL were: $9.8 \cdot 10^{-8}$ and $12 \cdot 10^{-8} M$ for $M$. luteus 128 and 140 , respectively. The MIC for $E$. coli 52 was $11 \cdot 10^{-8} M$. Consequently, DL possessing enzymatic (glycosidase) and non-enzymatic antibacterial activities may be a 'magic bullet' for pathogenic cells [6].

\section{Antimicrobial Activities of Some Amphipathic}

Peptides (Fragments of the DL Structure)

This activity was calculated as MIC of peptides inhibiting growth of some bacteria in solid and in liquid media. DL fragment $\alpha 2$ was practically inactive, DL fragment $\alpha 3$ expressed antimicrobial activity $\left(\mathrm{MIC}=0.18 \cdot 10^{-4} \mathrm{M}\right)$ only for M. luteus 128 in liquid medium. DL fragment $\alpha 1$ develops the effective antimicrobial activity in solid and liquid cell media: its MICs were $8.3 \cdot 10^{-5}$ and 3.5 . $10^{-6} M$ for $M$. luteus $128,4.9 \cdot 10^{-6}$ and $2.0 \cdot 10^{-6} M$ for E. coli $52,9.1 \cdot 10^{-5}$ and $1.1 \cdot 10^{-5} M$ for B. brevis 3 and
$1.40 \cdot 10^{-4} M$ and $2.1 \cdot 10^{-5} M$ for $S$. chrysomallus 257 , respectively. The antimicrobial activity of DL peptide fragment $\alpha 1$ is higher in liquid than in solid cell medium, but it is much lower than the antimicrobial activity of the whole DL molecule. Ibrahim et al. [2] have demonstrated that the non-enzymatic antibacterial activity of vertebrate chicken-type lysozymes is provided by a main protein fragment, a helix-loop-helix peptide repertoire acting separately or in concert. In most cases, this repertoire showed much more potent antibacterial activity than the single $\alpha$-helix peptides. Apparently, non-enzymatic antibacterial activity of invertebrate DL lacking the helixloop-helix peptide is also provided, not by the single $\alpha 1$ helix peptide but by peptide fragments acting in concert, which differ from those of chicken-type lysozymes.

\section{Acknowledgments}

The authors are grateful to Prof. E.D. Sverdlov, Russian Academy of Science, for valuable comments. This work was supported by the Russian Foundation for Basic Research, project No. 99-0448695 and 00-04-48166.

\section{References}

1 Zavalova LL, Baskova IP, Lukyanov SA, Sass AV, Snezhkov EV, Akopov SB, Artamonova II, Archipova VS, Nesmeyanov VA, Kozlov DG, Benevolensky SV, Kiseleva VI, Poverenny AM, Sverdlov ED: Destabilase from the medicinal leech is a representative of a novel family of lysozymes. Biochim Biophys Acta 2000; 1478:69-77.

\footnotetext{
2 Ibrahim H, Thomas U, Pellegrini A: A helixloop-helix peptide at the upper lip of the active site cleft of lysozyme confers potent antimicrobial activity with membrane permeabilization action. J Biol Chem 2001;276:43767-43774.

3 Baskova IP, Zavalova LL, Basanova AV, Sass AV: Separation of monomerizing and lysozyme activities of destabilase from medicinal leech salivary gland secretion. Biochemistry (Moscow) 2001;66:1368-1373.
}

4 Lanchini G, Parenty F: Antibiotics. New York, Springer, 1982.

$\checkmark 5$ Rost B, Sander C: Prediction of protein secondary structure at better than $70 \%$ accuracy. J Mol Biol 1993;232:584-599.

-6 Sorgel F: The return of Ehrlich's 'Therapia magna sterilisans' and other Ehrlich concepts? Series of papers honoring Paul Ehrlich on the occasion of his 150 th birthday. Chemotherapy 2004;50:6-10. 